\title{
PENGARUH LATAR BELAKANG PENDIDIKAN, PENGETAHUAN AKUNTANSI PEMILIK, DAN UKURAN USAHA KECIL MENENGAH (UKM) TERHADAP PENERAPAN SAK-ETAP DI KOTA SEMARANG
}

\author{
Yogi Ari Prakoso \\ Fakultas Ekonomi, Universitas Muhammadiyah Semarang \\ ari.yogi23@gmail.com \\ Andwiani Sinarasri \\ Fakultas Ekonomi, Universitas Muhammadiyah Semarang \\ andwi_fe@yahoo.com \\ Fatmasari Sukesti \\ Fakultas Ekonomi, Universitas Muhammadiyah Semarang \\ fatmasaris@yahoo.com
}

Riwayat Artikel: dikirim Oktober 2018, diterima September 2018, diterbitkan September 2018

\begin{abstract}
This research aims to prove evidence on the influence of owner's educational background, owner's accounting knowledge, and size of business towards the implementation of SAK ETAP on SMEs located in Semarang City used quantitative method by using primary data. Used 83 samples with determination used the slovin formula.

In this research used IBM SPSS for Windows, 23 with three independent variables are owner's educational background, owner's accounting knowledge, and size of business and the implementation of SAK ETAP as the dependent variable. The testing data used instrument test to consist of validity test and reliability test, classic assumption test which consist of normality test, multikolinierity test, heteroskedastisity test, and autocorrelation, together with hypotesys test which covers f-test and t-test.

The results show that the owner's educational background do positive and not significantly effect on the implementation of SAK ETAP, owner's accounting knowledge do positive and significantly effect on the implementation of SAK ETAP, and size of business do positive and significantly effect on the implementation on the SAK ETAP partially, and taken tog ether simultaneously test do positive and significantly effect on the implementation of SAK ETAP.
\end{abstract}

Keyword: owner's educational background, owner's accounting knowledge, business scale, implementation of SAK ETAP 


\section{PENDAHULUAN}

Usaha Mikro, Kecil dan Menengah (UMKM) merupakan ekonomi rakyat yang memiliki lingkup kecil yang berdiri sendiri dan dikelola oleh perorangan atau kelompok. UMKM memengaruhi perekonomian Indonesia karena dapat menyerap tenaga kerja dan mengurangi pengangguran, selain itu juga memberikan kontribusi yang tinggi bagi Produk Domestik Bruto (PDB) Indonesia. Pada tahun 2013, perkembangan UMKM mencapai 2,41\% dari tahun 2012 dan UMKM di Indonesia berjumlah 57.895.721 unit yang meningkat sebanyak 1.361.129 dari tahun sebelumnya. UMKM dan Usaha Besar memberikan kontribusi PDB bagi Indonesia sebanyak 60\% (Kementrian Koperasi dan Usaha Kecil Menengah Republik Indonesia, 2013). Pada awal tahun 2016 dengan adanya Masyarakat Ekonomi Asean (MEA) masuk ke Indonesia dan seluruh lingkup ASEAN menjadikan pasar Indonesia semakin bebas dan persaingan pasar semakin besar.

Fenomena terbaru pada tanggal 24 April 2017 yang dikutip dari laman liputan6.com menyebutkan bahwa Wakil Presiden Jusuf Kalla menyatakan, pemerintah akan menurunkan tingkat suku bunga Kredit Usaha Rakyat (KUR) menjadi 7 persen pada 2017. Hal tersebut bertujuan untuk mendorong Usaha Mikro Kecil dan Menengah (UMKM). Realisasi Kredit Usaha Rakyat (KUR) sepanjang 1 Januari - 31 Desember 2017 mencapai Rp96,71 triliun atau sebesar 87,9\% dari angka yang ditargetkan Rp110 triliun tersebut melalui 40 lembaga keuangan penyalur, yakni 34 perbankan, 4 lembaga keuangan dan 2 koperasi dengan jumlah debitur mencapai 4.086.971 orang.

Penyaluran kredit dilakukan 15

bank umum nasional yang telah menyalurkan sebesar Rp 94.261.219.000.000 dengan jumlah debitur 4.057.069 orang dan 19 bank pembangunan daerah telah merealisasikan Rp2.442.244.000.000 dengan debitur 29.418 orang. Untuk lembaga keuangan PENGARUH LATAR BELAKANG PENDIDIKAN...

Yogi Ari Prakoso, Andwiani Sinarasri, Fatmasari Sukesti DOI non bank sebanyak 4 penyalur telah merealisasikan Rp 1.066.000.000 dengan debitur 87 orang dan 2 koperasi menyalurkan sebesar Rp 9.052.000.000 dengan jumlah debitur 397 orang (Kementerian Koordinator Bidang Perekonomian).

Para pelaku UMKM yang belum menyusun laporan keuangan sesuai SAK ETAP atas operasionalnya, maka akan kesulitan mengemukakan informasi keuangan usahanya. Selain kesulitan mengemukakan informasi keuangan, pemilik UMKM juga akan sulit untuk mengetahui faktor apa saja yang kurang baik dalam kinerja operasional usaha. Tidak semua pemilik UMKM memiliki latar belakang pendidikan yang cukup baik dan pengetahuan tentang penyusunan laporan dan yang berbasis SAK ETAP. Rahmawati dan Puspasari (2017) menyatakan bahwa ukuran usaha, lama usaha berdiri, pemberian informasi dan sosialisasi SAK ETAP, latar belakang pendidikan dan jenjang pendidikan terakhir pelaku usaha, serta profesionalisme manajemen berpengaruh terhadap pemahaman pelaku UMKM terkait implementasi SAK ETAP sedangkan penelitian yang dilakukan Dewi (2016) berpendapat bahwa latar belakang pendidikan, umur usaha, dan skala usaha tidak berpengaruh positif terhadap penyusunan laporan keuangan berbasis SAK ETAP.

Ukuran usaha yang semakin berkembang maka akan membutuhkan informasi yang lebih kompleks dan juga membutuhkan laporan keuangan untuk menghasilkan informasi keuangan secara periodik. Pratiwi dan Hanafi (2016) berpendapat bahwa Pendidikan pemilik, pemahaman teknologi informasi, karakteristik kualitatif laporan keuangan dan ukuran usaha berpengaruh positif signifikan terhadap penerapan SAK ETAP pada UMKM. Penelitian yang dilakukan Pratiwi dan Hanafi (2016) tidak sejalan dengan penelitian yang dilakukan Dewi (2016) yang menyatakan bahwa bahwa latar belakang pendidikan, umur usaha, 
dan skala usaha tidak berpengaruh positif terhadap penyusunan laporan keuangan berbasis SAK ETAP pada UMKM. Para pemilik UMKM tidak selalu memperhatikan laporan keuangan yang seharusnya disusun dengan berstandarkan SAK ETAP. Dari latar belakang permasalahan tersebut, dirumuskan menjadi Pengaruh Latar Belakang Pendidikan, Pengetahuan Akuntansi Pemilik, dan Ukuran Usaha kecil dan menengah (UKM) terhadap Penerapan SAK ETAP.

\section{LANDASAN TEORI}

\section{Theory of Planned Behavior}

Theory of Planned Behavior

(TPB) merupakan pengembangan dari Theory of Reasoned Action (TRA), selanjutnya teori tersebut terus direvisi dan diperluas oleh Icek Ajzen dan Martin Fishbein (2005) . TRA diaplikasikan pada perilaku yang di bawah kendali individu sendiri. Sebaliknya, TPB dikembangkan untuk memprediksi perilaku-perilaku yang sepenuhnya tidak di bawah kendali individu. TPB menjelaskan bahwa niat berperilaku (behavioral intention) tidak hanya dipengaruhi oleh sikap terhadap perilaku (attitude towards behavior) dan norma subyektif (subjective norm), tetapi juga dipengaruhi oleh kontrol keperilakuan yang dirasakan (perceived behavioral control).

Berdasarkan Theory of Planed Behavior, intensi merupakan fungsi dari tiga determinan, pertama yang bersifat personal, kedua merefleksikan pengaruh sosial dan ketiga berhubungan dengan masalah kontrol (Ajzen, 2005:34).

\section{Latar Belakang Pendidikan}

Latar belakang pendidikan adalah yang dapat membedakan tingkat rendahnya tingkat pemahaman yang dimiliki oleh pemilik UKM. Pemilik UMKM dengan latar belakang pendidikan selain akuntansi atau ekonomi cenderung lebih lama dan sulit dalam memahami penyusunan laporan keuangan berdasarkan SAK ETAP daripada PENGARUH LATAR BELAKANG PENDIDIKAN...

Yogi Ari Prakoso, Andwiani Sinarasri, Fatmasari Sukesti pengusaha UMKM dengan latar belakang pendidikan akuntansi atau ekonomi (Rudiantoro dan Siregar, 2011).

\section{Pengetahuan Akuntansi}

Pengetahuan akuntansi adalah pengetahuan tentang akuntansi yang dimiliki oleh pengusaha kecil dan menengah. Menurut Jusuf (2003:5) akuntansi adalah proses pencatatan, penggolonggan, ringkasan, pelaporan, dan penganalisaan data keuangan suatu organisasi. Proses belajar mengenai akuntansi akan menningkatkan pengetahuan akuntansi pengusaha (manager), sehingga pemahaman pengusaha (manager) untuk menerapkan informasi akuntansi juga akan semakin meningkat.

\section{Ukuran Usaha}

Holmes dan Nicholls (1998, dalam Grace 2003) dalam Mulyani (2012) mendefinisikan ukuran perusahaan merupakan kemampuan perusahaan dalam mengelola usahanya dengan melihat total asset, berapa jumlah karyawan yang dipekerjakan, dan berapa besar pendapatan yang diperoleh perusahaan dalam satu periode akuntansi. Ukuran usaha akan mempengaruhi pemilik usaha untuk menentukan langhah dalam memutuskan untuk menggunakan akuntansi. Semakin besar ukuran usaha akan memberikan dampak yang lebih kompleks bagi usaha untuk mencaat pemasukan dan pengeluaran dalam operasional.

\section{Standar Akuntansi Keuangan Entitas Tanpa Akuntabilitas Publik (SAK ETAP)}

SAK ETAP adalah Standar Akuntansi Keuangan untuk Entitas Tanpa Akuntabilitas Publik. ETAP yaitu Entitas yang tidak memiliki akuntabilitas publik yang signifikan serta menerbitkan laporan keuangan untuk tujuan umum bagi pengguna eksternal. Laporan Keuangan SAK ETAP terdiri dari Neraca, Laporan Laba Rugi, Laporan Perubahan Ekuitas 
dan Laporan Laba Rugi dan Saldo Laba, Laporan Arus Kas, dan Catatan Atas Laporan Keuangan.

\section{Kriteria UMKM}

Sesuai dengan Undang-Undang RI Nomor 28 tahun 2008, UMKM memiliki diklasifikasikan sebagai berikut:

1. Kriteria Usaha Mikro adalah sebagai berikut:

a. memiliki kekayaan bersih paling banyak Rp50.000.000,00 (lima puluh juta rupiah) tidak termasuk tanah dan bangunan tempat usaha; atau

b. memiliki hasil penjualan tahunan paling banyak Rp300.000.000,00 (tiga ratus juta rupiah).

2. Kriteria Usaha Kecil adalah sebagai berikut:

a. memiliki kekayaan bersih lebih dari Rp50.000.000,00 (lima puluh juta rupiah) sampai dengan paling banyak Rp500.000.000,00 (lima

ratus juta rupiah) tidak termasuk tanah dan bangunan tempat usaha; atau

b. memiliki hasil penjualan tahunan lebih dari Rp300.000.000,00 (tiga ratus juta rupiah) sampai dengan paling banyak Rp2.500.000.000,00 (dua milyar lima ratus juta rupiah).

3. Kriteria Usaha Menengah adalah sebagai berikut:

a. memiliki kekayaan bersih lebih dari Rp500.000.000,00 (lima ratus juta rupiah) sampai dengan paling banyak Rp10.000.000.000,00 (sepuluh milyar rupiah) tidak termasuk tanah dan bangunan tempat usaha; atau

b. memiliki hasil penjualan tahunan lebih dari Rp2.500.000.000,00 (dua milyar lima ratus juta rupiah) sampai dengan paling banyak Rp50.000.000.000,00 (lima puluh milyar rupiah).

\section{Kerangka Pemikiran}

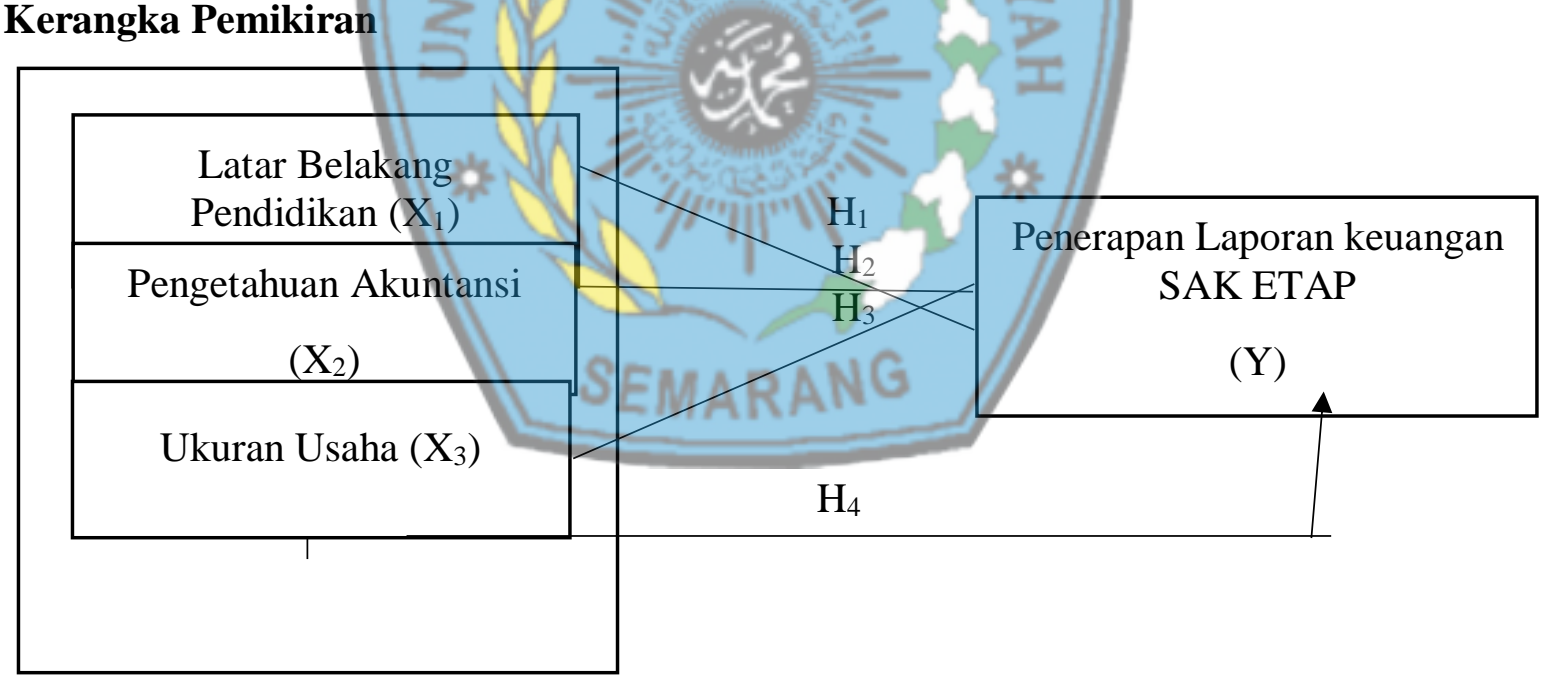

Hipotesis Penelitian

H1 : Latar belakang pendidikan berpengaruh terhadap penerapan SAK ETAP

H2 : Pengetahuan akuntansi berpengaruh terhadap penerapan SAK ETAP

\section{METODE PENELITIAN}

Populasi, Sampel, dan Metode

Pengambilan Sampel
H3 : Ukuran usaha berpengaruh terhadap penerapan SAK ETAP

H4 : Latar belakang pendidikan, pengetahuan akuntansi pemilik, dan ukuran usaha berpengaruh secara simultan terhadap penerapan SAK ETAP.

\section{Populasi dan Sampel}

Populasi menurut Sugiyono (2012) adalah wilayah generalisasi yang 
terdiri atas obyek atau subyek yang mempunyai kualitas dan karakteristik tertentu yang ditetapkan oleh peneliti untuk dipelajari dan ditarik kesimpulannya. Populasi dalam penelitian ini adalah UKM yang berada di kota semarang. Responden dalam penelitian ini adalah pemilik dan/atau manajer UKM yang berada di Kota Semarang yang berjumlah 475 UKM yang memiliki klasifikasi usaha kecil hingga menengah. Sampl pada penelitian ini adalah UKM yang bergerak di segala bidang di kota semarang yang berjumlah 83 UKM.

\section{Metode Pengambilan Sample}

\section{Dalam \\ penelitian}

menggunakan teknik simple

Metode pengumpulan data yang dipakai dalam penelitian ini adalah angket atau kuesioner. Angket atau kuesioner yaitu teknik pengumpulan data yang dilakukan dengan cara memberi seperangkat pertanyaan atau pertanyaan tertulis kepada responden untuk dijawabnya (Sugiyono, 2012).

Metode Analisis

\section{Analisis Regresi Linier Berganda}

Regresi

berganda

pengembangan dari regresi linier
sederhana, yaitu sama-sama alat yang dapat digunakan untuk memprediksi permintaan di masa yang akan datang berdasarkan data masa lalu atau untuk mengetahui pengaruh satu atau lebih variabel bebas (independen) terhadap satu variabel tak bebas (dependen) (Siregar,2012:301).

Bentuk analisis regresi linier berganda ini mempunyai bentuk umum persamaan sebagai berikut :

$$
\mathrm{Y}=\mathrm{a}+\mathrm{b} 1 \mathrm{X} 1+\mathrm{b} 2 \mathrm{X} 2+\mathrm{b} 3 \mathrm{X} 3 \mathrm{e}
$$

\section{Uji Validitas}

Kriteria keputusan kesahihan dinyatakan apabila nilai $r$ yang diperoleh Pengujian Asumsi Klasik terdapat 4 uji yang harus dilakukan. Uji tersebut antara lain: 1) uji normalitas, sampling. Indriantoro dan Supomo (2012) menyatakan bahwa simple random sampling adalah metode penelitian sample secara acak sederhana memberikan kesempatan yang sama yang bersifat tak terbatas pada setiap elemen populasi untuk dipilih sebagai sample.

\section{Jenis Data, Sumber Data, dan Metode Pengambilan Data}

Data yang digunakan dalam penelitian ini adalah data primer. Data Primer menurut Indriantoro dan Supomo (2002) merupakan sumber data penilitian yang diperoleh secara langsung dari sumber asalnya. dari hasil perhitungan (rxy) lebih besar daripada nilai rtabel (rt) dengan taraf signifikansi $5 \%$, atau nilai signifikansi < 0,05 maka butir-butir pertanyaan kuesioner adalah valid atau sahih.

\section{Uji Reliabilitas}

\section{Uji reliabilitas digunakan untuk} mengetahui apakah hasil pengukuran dapat konsisten yaitu apakah alat ukur yang ada dapat diterapkan pada objek yang sama secara berulang dan menghasilkan ukuran yang mendekati sebelumnya (Singarimbun dan Efendi, 2005: 65). Hasil dari pengujian ini dinyatakan dalam bentuk keefisien reliabilitas seluruh pertanyaan yang terdapat dalam instrumen variabel yang sedang diuji. Kriteria keputusan reliabel tidaknya kuesioner dinyatakan apabila nilai koefisien Cronbach Alpha > 0,60 adalah reliabel, maka butir-butir kuesioner tersebut dapat diandalkan atau dengan kata lain reliabel.
Dalam pengujian asumsi klasik, bertujuan untuk menguji apakah variabel residual dalam model regresi mempunyai 
distribusi normal atau tidak. Uji F dan uji $\mathrm{t}$ mengasumsikan bahwa nilai residual mengikuti distribusi normal. Penelitian ini menggunakan uji normalitas dengan alat uji satu sampel Kolmogorov Smirnov (ks). Kriteria pengujian jika nilai signifikansi > 0,05 maka lolos uji normalitas. 2) Uji multikolinierita, bertujuan untuk menguji apakah model regresi ditemukan adanya korelasi antar variabel bebas (independen). Model regresi yang baik seharusnya tidak terjadi korelasi diantara variabel independen (Ghozali, 2011: 108). Untuk mendeteksi apakah model regresi linear mengalami multikolinearitas dapat dilihat menggunakan Variance Inflation Factor (VIF) dan nilai toleransi untuk masingmasing variabel bebas. Model regresi bebas multikolinearitas memiliki VIF di bawah 10 dan nilai toleransi di atas $0,1.3$ ) Uji heteroskedastisitas, bertujuan untuk menguji apakah dalam model regresi terjadi ketidaksamaan variance dari residual satu pengamatan ke pengamatan lain. Deteksi ada tidaknya heteroskedastisitas dilakukan dengan uji glejser, apabila signifikansinya $<0,05$ artinya terjadi heteroskedastisitas. Sebaliknya, jika signifikansinya $>0,05$ maka tidak terjadi heteroskedastisitas. Deteksi heteroskedastisitas dapat dilakukan dengan metode scatter plot dengan memplotkan nilai ZPRED (nilai prediksi) dengan SRESID (nilai residunya). Model yang baik didapatkan jika tidak terdapat pola tertentu pada grafik, seperti mengumpul ditengah, menyempit kemudian melebar atau sebaliknya melebar kemudian menyempit. 4) Uji autokorelasi bertujuan menguji apakah dalam model regresi liniear ada korelasi antara kesalahan pengganggu pada periode $t$ dengan kesalahan pengganggu pada periode $\mathrm{t}-1$ (sebelumnya). Jika terjadi korelasi, maka dinamika ada problem autokorelasi. (Ghozali,2011:110) Ada beberapa cara untuk melakukan pengujian terhadap asumsi autokorelasi, salah satunya menggunakan Durbin-Watson test.
Durbin dan Watson telah mentabelkan nilai du dan dl untuk taraf $5 \%$ dan $1 \%$ yang dikenal dengan Tabel Durbin Watson.

\section{Pengujian Hipotesis}

1. Uji F

Uji $F$ digunakan untuk menguji pengaruh variabel independen (Latar Belakang Pendidikan, Pengetahuan Akuntansi, Modal, dan Ukuran Usaha) secara bersama-sama terhadap variabel dependen (Penerapan SAK ETAP).

\section{Uji Signifikansi (Uji t / Uji Parsial)}

Uji $t$ digunakan untuk menguji pengaruh variabel independen (Latar Belakang Pendidikan, Pengetahuan Akuntansi Pemilik, dan Ukuran Usaha) secara parsial terhadap variabel dependen (Penerapan SAK ETAP).

\section{Uji Koefisien Determinasi $\left(\mathbf{R}^{\mathbf{2}}\right)$}

Analisis $\mathrm{R}^{\mathbf{2}}$ digunakan untuk mengetahui besarnya presentase pengaruh semua variabel independen terhadap nilai variabel dependen. Nilai $\mathrm{R}^{2}$ akan berkisar 0 sampai 1. Niali $\mathrm{R}^{2}=1$ menunjukkan bahwa $100 \%$ total variasi diterangkan oleh variabel persamaan regresi atau variabel bebas, baik $X_{1}$ maupun $X_{2}$. Sebaliknya apabila $\mathrm{R}^{2}=0$ menunjukan bahwa tidak ada total varian bebas dari persamaan regresi baik $\mathrm{X}_{1}$ maupun $\mathrm{X}_{2}$ (Purwanto dan Suharyadi,2008:217).

\section{HASIL DAN PEMBAHASAN Deskripsi Data}

Obyek dalam penelitian ini adalah usaha yang bergerak di berbagai bidang usaha yang mempunyai skala kecil hingga menengah. Obyek penelitian yang dituju diberikan kepada usaha berbadan hukum $\mathrm{CV}$ dan usaha yang non CV. Kuesioner yang disebar sebanyak 83 buah tetapi yang dapat diolah sebanyak 72 buah.

\section{Analisis Statistik Deskriptif}

Deskriptif data dari setiap variabel penelitian mencakup nilai maksimum, minimum, mean dan standar deviasi dilakukan dengan uji statistik deskriptif menggunakan 
program SPSS 23 hasilnya dapat dilihat pada tabel 4.3 berikut:

Tabel 4.3

Statistik Deskriptif

\begin{tabular}{|l|r|r|r|r|r|}
\hline & $\mathrm{N}$ & Minimum & Maximum & Mean & $\begin{array}{c}\text { Std. } \\
\text { Deviation }\end{array}$ \\
\hline Latar belakang Pendidikan & 72 & 3 & 8 & 5.26 & 1.547 \\
Pengetahuan akuntansi & 72 & 33 & 64 & 45.49 & 7.894 \\
Ukuran Usaha & 72 & 5 & 15 & 10.28 & 2.999 \\
Valid N (listwise) & 72 & & & & \\
\hline
\end{tabular}

Sumber : Data diolah SPSS 23, 2018

\section{Uji Validitas}

Tabel 4.15

Hasil Uji Validitas Latar Belakang Pendidikan Pemilik (X1)

\begin{tabular}{|c|c|c|c|}
\hline $\begin{array}{c}\text { Butir } \\
\text { No }\end{array}$ & $\begin{array}{c}\text { Nilai Korelasi } \\
\text { (Pearson } \\
\text { Correlation) }\end{array}$ & Sig. (2 Tailed) & Keterangan \\
\hline X1_1 & 0,884 & 0,000 & Valid \\
\hline X1_2 & 0,871 & 0,000 & Valid \\
\hline
\end{tabular}

Sumber : Data diolah SPSS 23, 2018

Tabel 4.16

Hasil Uji Validitas Pengetahuan Akuntansi Pemilik (X2)

\begin{tabular}{|c|c|c|c|}
\hline Butir No & $\begin{array}{c}\text { Nilai Korelasi } \\
\text { (Pearson//7ij } \\
\text { Correlation) }\end{array}$ & $\begin{array}{c}\text { Sig. (2*- } \\
\text { Tailed) }\end{array}$ & Keterangan \\
\hline X2_1 & 0,652 & 0,000 & Valid \\
\hline X2_2 & 0,758 & 0,000 & Valid \\
\hline X2_3 & 0,758 & 0,000 & Valid \\
\hline X2_4 & 0,515 & 0,000 & Valid \\
\hline X2_5 & 0,701 & 0,000 & Valid \\
\hline X2_6 & 0,597 & 0,000 & Valid \\
\hline X2_7 & 0,791 & 0,000 & Valid \\
\hline X2_8 & 0,855 & 0,000 & Valid \\
\hline X2_9 & 0,474 & 0,000 & Valid \\
\hline X2_10 & 0,779 & 0,000 & Valid \\
\hline X2_11 & 0,615 & 0,000 & Valid \\
\hline X2_12 & 0,854 & 0,000 & Valid \\
\hline X2_13 & 0,703 & 0,000 & Valid \\
\hline
\end{tabular}

Sumber: Data diolah SPSS 23, 2018

Tabel 4.17

Hasil Uji Validasi Ukuran Usaha (X3)

\begin{tabular}{|c|c|c|c|}
\hline $\begin{array}{c}\text { Butir } \\
\text { No }\end{array}$ & $\begin{array}{c}\text { Nilai Korelasi } \\
\text { (Pearson Correlation) }\end{array}$ & Sig. (2 Tailed) & Keterangan \\
\hline X3_1 & 0,942 & 0,000 & Valid \\
\hline
\end{tabular}




\begin{tabular}{|l|l|l|l|} 
X3_2 & 0,930 & 0,000 & Valid \\
\hline X3_3 & 0,945 & 0,000 & Valid \\
\hline
\end{tabular}

Sumber: Data diolah SPSS 23, 2018

Tabel 4.18

Hasil Uji Validasi Penerapan SAK-ETAP (Y)

\begin{tabular}{|c|c|c|c|}
\hline $\begin{array}{c}\text { Butir } \\
\text { No }\end{array}$ & $\begin{array}{c}\text { Nilai Korelasi } \\
\text { (Pearson Correlation) }\end{array}$ & Sig. (2 Tailed) & Keterangan \\
\hline Y_1 & 0,426 & 0,000 & Valid \\
\hline Y_2 & 0,578 & 0,000 & Valid \\
\hline Y_3 & 0,703 & 0,000 & Valid \\
\hline Y_4 & 0,526 & 0,000 & Valid \\
\hline Y_5 & 0,385 & 0,001 & Valid \\
\hline Y_6 & 0,451 & 0,000 & Valid \\
\hline Y_7 & 0,501 & 0,000 & Valid \\
\hline Y_8 & 0,471 & 0,000 & Valid \\
\hline Y_9 & 0,673 & 0,000 & Valid \\
\hline Y_10 & 0,655 & 0,000 & Valid \\
\hline Y_11 & 0,609 & 0,000 & Valid \\
\hline Y_12 & 0,699 & 0,000 & Valid \\
\hline Y_13 & 0,560 & 0,000 & Valid \\
\hline Y_14 & 0,625 & 0,000 & Valid \\
\hline Y_15 & 0,647 & 0,000 & Valid \\
\hline Sumb : Dat & & \\
\hline
\end{tabular}

Sumber : Data diolah SPSS 23, 2018

Hasil Uji Reliabilitas

Tabel 4.19

Hasil Uji Reliabilitas

\begin{tabular}{|c|l|c|c|}
\hline No & \multicolumn{1}{|c|}{ Nama Variabel } & Alpha Cronbach & Keterangan \\
\hline 1 & Latar Belakang Pendidikan & 0,701 & Reliabel \\
\hline 2 & $\begin{array}{l}\text { Pengetahuan Akuntansi SE } \\
\text { Pemilik }\end{array}$ & $\begin{array}{c}\text { AR } 0,913 \\
\text { Reliabel }\end{array}$ \\
\hline 3 & Ukuran Usaha & 0,935 & Reliabel \\
\hline 4 & Penerapan SAK ETAP & 0,852 & Reliabel \\
\hline
\end{tabular}

Sumber : Data diolah SPSS 23, 2018

\section{Uji Asumsi Klasik}

1. Uji Normalitas

Tabel 4.20

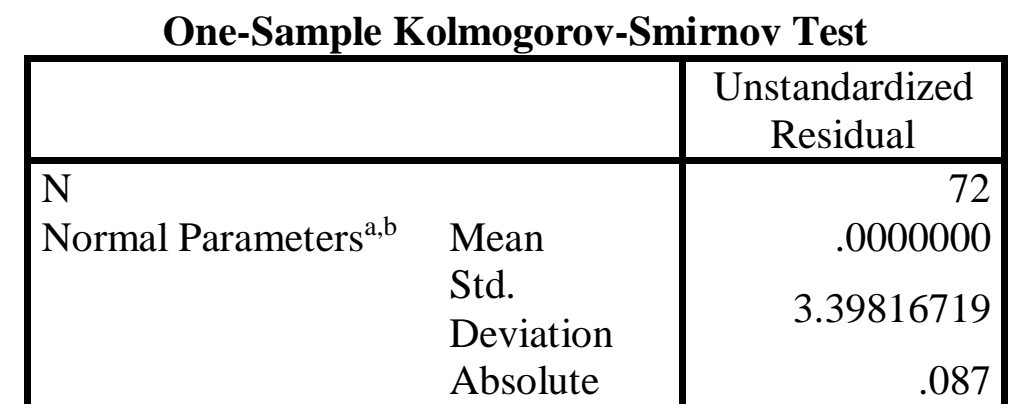

PENGARUH LATAR BELAKANG PENDIDIKAN...

Yogi Ari Prakoso, Andwiani Sinarasri, Fatmasari Sukesti 


\begin{tabular}{|ll|r|} 
Most Extreme & Positive & .083 \\
Differences & Negative & -.087 \\
Test Statistic & & .089 \\
Asymp. Sig. (2-tailed) & & .200 \\
\hline
\end{tabular}

Hasil Uji Normalitas

Sumber : Data diolah SPSS 23, 2018

Pengolahan data Kolmogorov Smirnov diperoleh nilai Test Statistic sebesar 0,089 dan signifikansinya adalah 0,200 > 0,05 yang berarti bahwa data berdistribusi normal.

\section{Uji Multikolinieritas}

Tabel 4.21

Uji Multikolinieritas

\begin{tabular}{|c|c|c|c|c|c|}
\hline \multirow[b]{2}{*}{ Model } & \multicolumn{2}{|c|}{ 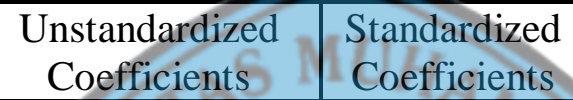 } & \multirow[b]{2}{*}{ Sig. } & \multicolumn{2}{|c|}{$\begin{array}{l}\text { Collinearity } \\
\text { Statistics }\end{array}$} \\
\hline & $\begin{array}{l}\text { Std. } \\
\text { Error }\end{array}$ & & & $\begin{array}{c}\text { Tolera } \\
\text { nce }\end{array}$ & VIF \\
\hline $1 \quad$ (Constant) & $36 \quad 2.448$ & & .000 & & \\
\hline $\begin{array}{l}\text { Latar belakang } \\
\text { pendidikan }\end{array}$ & & & .186 & .434 & 2.304 \\
\hline $\begin{array}{l}\text { Pengetahuan } \\
\text { akuntansi }\end{array}$ & & & .000 & .517 & 1.935 \\
\hline Ukuran usaha & 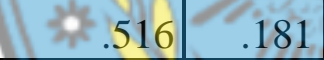 & .254 & .006 & .573 & 1.744 \\
\hline
\end{tabular}

Sumber : Data diolah SPSS 23, 2018

Tabel 4.21 di atas menunjukkan bahwa nilai VIF masing-masing berada di angka kurang dari 10, sedangkan nilai tollerance dibawah 1 . Hal ini menunjukkan bahwa variabel independen terhindar dari masalah multikolinieritas.

\section{Uji Heteroskedastisitas}

Tabel 4.22

Uji Glejser

Coefficients $^{\mathrm{a}}$

\begin{tabular}{|c|c|c|c|c|c|c|}
\hline \multirow{2}{*}{\multicolumn{2}{|c|}{ Model }} & \multicolumn{2}{|c|}{$\begin{array}{c}\text { Unstandardized } \\
\text { Coefficients }\end{array}$} & \multirow{2}{*}{$\begin{array}{c}\begin{array}{c}\text { Standardized } \\
\text { Coefficients }\end{array} \\
\text { Beta }\end{array}$} & \multirow[b]{2}{*}{$\mathrm{t}$} & \multirow[b]{2}{*}{ Sig. } \\
\hline & & B & Std. Error & & & \\
\hline \multirow[t]{4}{*}{1} & (Constant) & -3.112 & 1.369 & & -2.274 & .026 \\
\hline & $\begin{array}{l}\text { Latar belakang } \\
\text { pendidikan }\end{array}$ & .360 & .226 & .252 & 1.594 & .116 \\
\hline & Pengetahuan akuntansi & .076 & .041 & .270 & 1.860 & .067 \\
\hline & Ukuran usaha & .034 & .101 & .046 & .331 & .742 \\
\hline
\end{tabular}

Sumber : Data diolah SPSS 23, 2018

PENGARUH LATAR BELAKANG PENDIDIKAN... 
Hasil uji heteroskedastisitas

tabel diatas menggunakan uji Glejser yang menunjukkan nilai signifikansi variabel latar belakang pendidikan sebesar 0,971, nilai signifikansi variabel pengetahuan akuntansi sebesar 0,051, dan nilai

\section{Uji Autokorelasi}

signifikansi variabel ukuran usaha sebesar 0,438 . Keseluruhan data tersebut nilainya lebih besar dari 0,05 yang berarti model regresi yang digunakan tidak terjadi heteroskedastisitas antar residual.

Tabel 4.23

Hasil Uji Autokorelasi

Model Summary ${ }^{b}$

\begin{tabular}{|l|c|r|r|r|r|}
\hline Model & $\mathrm{R}$ & R Square & $\begin{array}{c}\text { Adjusted R } \\
\text { Square }\end{array}$ & $\begin{array}{c}\text { Std. Error of } \\
\text { the Estimate }\end{array}$ & $\begin{array}{l}\text { Durbin- } \\
\text { Watson }\end{array}$ \\
\hline 1 & $.860^{\mathrm{a}}$ & .739 & .728 & 3.472 & 1.658 \\
\hline
\end{tabular}

Sumber : Data diolah SPSS 23, 2018

Dari hasil pengolahan data dapat diketahui bahwa nilai Durbin Watson

$\mathrm{d}_{\mathrm{U}}$ dan $\mathrm{d}_{\mathrm{L}}$ dalam tabel Durbin

Watson Statistics 5\% significance dengan $\mathrm{N}=72$ dan $\mathrm{k}=4$, kemudian di dapat nilai $\mathrm{d}_{\mathrm{L}}=1,502$ dan nilai $\mathrm{d}_{\mathrm{U}}=1736$. Maka nilai adalah 1,658. Nilai ini kemudian dibandingkan dengan nilai

Durbin Watson berada pada posisi $\mathrm{d}_{\mathrm{L}} \leq \mathrm{d}$ $\leq \mathrm{du}_{\mathrm{U}}(1,502 \leq 1,658 \leq 1,736)$ maka dapat disimpulkan bahwa data tidak terjadi autokorelasi.

\section{Analisis Regresi Linier Berganda}

\section{Tabel 4.24}

Hasil Analisis Regresi linier Berganda

Coefficients $^{\mathrm{a}}$

\begin{tabular}{|c|c|c|c|c|c|c|}
\hline \multirow{2}{*}{\multicolumn{2}{|c|}{ Model }} & \multicolumn{2}{|c|}{$\begin{array}{l}\text { Unstandardized } \\
\text { Coefficients AN }\end{array}$} & $\begin{array}{l}\text { Standardized } \\
\text { Coefficients }\end{array}$ & \multirow[b]{2}{*}{$\mathrm{T}$} & \multirow[b]{2}{*}{ Sig. } \\
\hline & & $\mathrm{B}$ & Std. Error & Beta & & \\
\hline 1 & (Constant) & 21.236 & 2.448 & & 8.676 & .000 \\
\hline & $\begin{array}{l}\text { Latar belakang } \\
\text { pendidikan }\end{array}$ & .540 & .404 & .126 & 1.337 & .186 \\
\hline & $\begin{array}{l}\text { Pengetahuan } \\
\text { akuntansi }\end{array}$ & .515 & .073 & .611 & 7.096 & .000 \\
\hline & Ukuran usaha & .516 & .181 & .232 & 2.842 & .006 \\
\hline
\end{tabular}

Sumber : Data diolah SPSS 23, 2018

Berdasarkan hasil uji analisis regresi linier berganda diperoleh hasil persamaan model regresi linier berganda sebagai berikut:
Penerapan SAK ETAP $=21.236+$ $0,540 \mathrm{X} 1+0,515 \mathrm{X} 2+0,516 \mathrm{X} 3+\mathrm{e}$ 


\section{Uji Hipotesis}

\section{Uji t (Uji Parsial)}

Tabel 4.25

Hasil Uji t

\section{Coefficients $^{\text {a }}$}

\begin{tabular}{|c|c|c|c|c|c|c|}
\hline & & \multicolumn{2}{|c|}{$\begin{array}{c}\text { Unstandardized } \\
\text { Coefficients }\end{array}$} & $\begin{array}{l}\text { Standardized } \\
\text { Coefficients }\end{array}$ & \multirow[b]{2}{*}{$\mathrm{T}$} & \multirow[b]{2}{*}{ Sig. } \\
\hline \multicolumn{2}{|c|}{ Model } & B & Std. Error & Beta & & \\
\hline \multirow[t]{4}{*}{1} & (Constant) & 21.236 & 2.448 & & 8.676 & .000 \\
\hline & $\begin{array}{l}\text { Latar belakang } \\
\text { pendidikan }\end{array}$ & .540 & .404 & .126 & 1.337 & .186 \\
\hline & $\begin{array}{l}\text { Pengetahuan } \\
\text { akuntansi }\end{array}$ & & & .611 & 7.096 & .000 \\
\hline & Ukuran usaha & .516 & 181 & .232 & 2.842 & .006 \\
\hline
\end{tabular}

Sumber : Data diolah SPSS 23, 2018

Berdasarkan tabel 4.25 diatas, variabel latar belakang pendidikan memiliki koefisien 0,540 dan hasil $t_{\text {hitung }}$ sebesar 1.752. Dengan perbandingan t hitung $<\mathrm{t}$ tabel $(1.752<1995)$ dan dengan tingkat signifikansi 0,186 lebih besar dari nilai signifikansi 0,05 maka dapat disimpulkan terdapat pengaruh positif tidak signifikan terhadap penerapan SAK ETAP, variabel pengetahuan akuntansi memiliki koefisien 0,515 dan hasil $t_{\text {hitung }}$ sebesar 7.096. Dengan perbandingan $\mathrm{t}$ hitung $>\mathrm{t}$ tabel $(7.096>1995)$ dan

\section{Uji F (Uji Simultan)}

signifikansi 0,00 lebih kecil dari nilai signifiknsi 0,05 maka dapat disimpulkan terdapat pengaruh positif dan signifikan terhadap penerapan SAK ETAP, variabel ukuran usaha memiliki koefisien 0,516 dan hasil thitung sebesar 2.842. Dengan perbandingan $t$ hitung $>t$ tabel $(2.842>1995)$ dan signifikansi 0,006 lebih kecil dari nilai signifikansi 0,05 maka dapat ditarik kesimpulan terdapat pengaruh positif dan signifikan terhadap penerapan SAK ETAP.

Tabel 4.27

Hasil Uji F

ANOVA $^{a}$

\begin{tabular}{|rl|r|r|r|r|r|}
\hline \multicolumn{2}{|c|}{ Model } & \multicolumn{1}{|c|}{$\begin{array}{c}\text { Sum of } \\
\text { Squares }\end{array}$} & Df & Mean Square & F & Sig. \\
\hline 1 & Regression & 2322.777 & 3 & 774.259 & 64.217 & $.000^{\mathrm{b}}$ \\
& Residual & 819.875 & 68 & 12.057 & & \\
& Total & 3142.653 & 71 & & & \\
\hline
\end{tabular}

Sumber : Data diolah SPSS 23, 2018

Pada tabel ANOVA dapat dilihat

Fhitung sebesar 64.217, sedangkan nilai
$F_{\text {tabel }}$ sebesar 2,50, karena $F_{\text {hitung }}>F_{\text {tabel }}$, dan nilai signifikansi $0,000<0,05$ maka 
Ho ditolak dan Ha diterima, berarti secara bersama-sama variabel latar belakang akuntansi, pengetahuan akuntansi, dan Uji Koefisien Determinan $\left(\mathbf{R}^{\mathbf{2}}\right)$ ukuran usaha berpengaruh signifikan terhadap variabel dependen yaitu penerapan SAK ETAP.

Tabel 4.28

Hasil Uji Koefisien Determinan

Model Summary ${ }^{b}$

\begin{tabular}{|l|r|r|r|r|r|}
\hline Model & R & R Square & $\begin{array}{c}\text { Adjusted R } \\
\text { Square }\end{array}$ & $\begin{array}{l}\text { Std. Error of } \\
\text { the Estimate }\end{array}$ & $\begin{array}{c}\text { Durbin- } \\
\text { Watson }\end{array}$ \\
\hline 1 & $.860^{\mathrm{a}}$ & .739 & .728 & 3.472 & 1.658 \\
\hline
\end{tabular}

Sumber : Data diolah SPSS 23, 2018

Pada tabel uji koefiesien determinan terlihat nilai R Square sebesar 73,9\%. Hal ini berarti bahwa 73,9\% penerapan SAK ETAP dipengaruhi oleh variabel latar belakang pendidikan

PEMBAHASAN

1. Pengaruh Latar Belakang Pendidikan terhadap Penerapan SAK ETAP

Berdasarkan hasil uji hipotesis $\mathrm{H}_{1}$ yang berbunyi latar belakang pendidikan berpengaruh positif tidak signifikan terhadap penerapan SAK ETAP dengan koefisien 0,540 dan $t$ hitung $<$ tabel $(1.752<$ 1995) serta signifikansi sebesar 0,186

terhadap penerapan SAK ETAP. Latar belakang pendidikan berpengaruh positif terhadap penerapan SAK ETAP karena responden yang memiliki latar belakang pendidikan akuntansi atau manajemen atau ekonomi cukup berimbang dengan yang berlatar belakang non ekonomi. Pemilik UKM yang memiliki latar belakang pendidikan dalam bidang ekonomi akan memudahkan dalam menyusun laporan keuangan sesuai SAK ETAP karena dapat membuat laporan keuangan dan selanjutnya disesuaikan dengan standar laporan keuangan UKM yang berlaku.

\section{Pengaruh Pengetahuan Akuntansi terhadap Penerapan SAK ETAP}

Berdasarkan hasil pengujian hipotesis menunjukkan bahwa nilai koefisien 0,515 dan $t_{\text {hitung }}>t_{\text {tabel }}$ (7.096> pemilik, pengetahuan akuntansi pemilik, dan ukuran usaha sedangkan sisanya sebesar $26,1 \%$ dipengaruhi oleh variabel lain diluar model ini.

yang berarti lebih besar dari nilai signifikan 0,05 atau 5\%. Dapat disimpulkan bahwa latar belakang pendidikan berpengaruh positif tidak signifikan terhadap penerapan SAK ETAP. Hasil penelitian ini sejalan dengan penelitian yang dikemukakan oleh Rudiantoro dan Siregar (2012) yang menyatakan bahwa latar belakang pendidikan berpengaruh positif

1995) dan signifikansi sebesar 0,000 yang berarti lebih kecil dari nilai signifikan 0,05 atau 5\%. Dapat disimpulkan bahwa pengetahuan akuntansi berpengaruh positif dan signifikan terhadap penerapan SAK ETAP. Hasil penelitian ini sejalan dengan penelitian yang dilakukan oleh Dewi (2015) yang menyatakan bahwa pengetahuan akuntansi berpengaruh positif dan signifikan terhadap penerapan SAK ETAP. Penelitian ini sejalan dengan Theory Planned Behavior dimana intensi akan memberikan pertimbangan pelaku usaha untuk memberikan dorongan dalam memperoleh pengetahuan akuntansi. Pengetahuan Akuntansi yang baik diperlukan oleh pemilik atau manajer usaha kecil menengah guna mengelola usahanya dan supaya dapat melakukan pembukuan laporan keuangan sesuai 
standar yang berlaku dari usaha yang dijalankan.

\section{Pengaruh Ukuran Usaha terhadap Penerapan SAK ETAP}

Berdasarkan hasil pengujian hipotesis menunjukkan bahwa nilai koefisien 0,516 dan $\mathrm{t}_{\text {hitung }}>\mathrm{t}_{\text {tabel }}(2.842>$ 1.995) dan signifikansi sebesar 0,006 yang berarti lebih kecil dari nilai signifikan 0,05 atau 5\%. Dapat disimpulkan bahwa ukuran usaha berpengaruh positif dan signifikan terhadap penerapan SAK ETAP. Ukuran usaha yang besar akan memberikan pengaruh pada pemilik usaha untuk menyusun laporan keuangan guna memberikan informasi secara periodik dan laporan keuangan dapat pula digunakan untuk meminjam dana kepada lembaga keuangan untuk mengembangkan usahanya. Hasil penelitian ini sejalan dengan penelitian yang dilakukan oleh Ayu Soraya dan Mahmud (2016) yang menyatakan bahwa ukuran usaha berpengaruh terhadap penerapan SAK ETAP. Penelitian ini sejalan dengan Theory Planned Behavior dalam salah satu varibel yakni intensi dimana intensi dapat mengarahkan tindakan sesuai dengan pertimbangan yang mendalam berdasarkan ukuran usaha yang dimiliki.

\section{Kesimpulan}

Berdasarkan hasil analisis dan pembahasan yang telah diuraikan, maka dapat diambil kesimpulan sebagai berikut: 1. Berdasarkan hasil analisis data diketahui bahwa latar belakang pendidikan berpengaruh positif tidak signifikan terhadap penerapan SAK ETAP.

2. Berdasarkan hasil analisis data diketahui bahwa pengetahuan akuntansi berpengaruh positif dan signifikan terhadap penerapan SAK ETAP.

3. Berdasarkan hasil analisis data diketahui bahwa ukuran usaha berpengaruh positif dan signifikan terhadap penerapan SAK ETAP.
4. Berdasarkan hasil analisis data diketahui bahwa latar belakang pendidikan, pengetahuan akuntansi, modal, dan ukuran usaha berpengaruh signifikan terhadap penerapan SAK ETAP. Dapat disimpulkan bahwa latar belakang pendidikan, pengetahuan akuntansi, modal, dan ukuran usaha secara bersama-sama berpengaruh terhadap penerapan SAK ETAP

\section{Saran}

Berdasarkan penelitian dapat ditemukan saran sebagai berikut:

1. Temuan dari penelitian ini adalah bahwa terdapat pengaruh pengetahuan akuntansi terhadap Implementasi SAK ETAP diharapkan pelaku usaha dapat lebih meningkatkan pengetahuan dan pemahaman akuntansi untuk lebih memudahkan dalam penyusunan laporan keuangan bersatandar SAK ETAP dan dapat mengikuti pelatihanpelatihan akuntansi.

2. Pada penelitian ini variabel intensi dalam Theory Planned Behavior menjadi penentu dan diharapkan pada penelitian selanjutnya dapat menggunakan variabel sikap seseorang terhadap perilaku dan norma subjektif dalam teori Theory Planned Behavior.

3. Penelitian selanjutnya diharapkan dapat menggunakan variabel yang berbeda dalam usaha kecil menengah dan dapat lebih spesifik kepada salah satu bidang usaha, misalnya dalam bidang jasa, industri, dan lainnya.

\section{DAFTAR PUSTAKA}

Ajzen, I dan Fisbein, M. 2005. Attitude, Personality, and Behavior. Buckingham: Open University Press, Milton Keynes.

Dewi, Anggunan Ersanti. 2016. Analisis Faktor-Faktor Yang Mempengaruhi Penyusunan Laporan Keuangan Berbasis SAK ETAP Pada Usaha Mikro Kecil 
dan Menengah Di Bandar Lampung, Skripsi, Fakultas Ekonomi dan Bisnis, Universitas Lampung.

Ghozali, Imam. 2011. "Aplikasi Analisis Multivariate Dengan Program SPSS", Badan Penerbit Universitas Diponegoro, Semarang.

Holmes, And Nicholls. (1998). An Analysis of the use of accounting information by australian small business. Journal of small business management, 26(20). 57-68

http://kur.ekon.go.id/realisasi_kur/2017/ $\underline{2}$

Ikatan Akuntan Indonesia, 2009. Standar Akuntansi Keuangan Entitas Tanpa Akuntabilitas Publik, Dewan Standar Akuntansi Keuangan, Jakarta.

Indriantoro, dan Supomo, 2002 Metodologi Penelitian Bisnis untuk Akuntansi dan Manajemen, Edisi Pertama, BPFE-Yogyakarta, Yogyakarta.
Mulyani, Sri, 2014. Faktor-Faktor Yang Mempengaruhi Kualitas Laporan Keuangan Pada UMKM di Kabupaten Kudus, JDEB Vol. 11 No. 2 Oktober 2014. Universitas Muria Kudus.

Rudiantoro, Rizki. dan Siregar, Sylvia Veronica., 2012. Kualitas Laporan Keuangan UMKM Serta Prospek Implementasi SAK ETAP. Jurnal Akuntansi dan Keuangan Indonesia Volume 9 - No. 1, Juni 2012. Universitas Indonesia.

Purwanto dan Suharyadi, 2008. Statistika Untuk Ekonomi dan Keuangan Modern. Salemba Empat, Jakarta.

Pratiwi, Nurita Budi dan Hanafi, Rustam. 2016. Analisis Faktor Yang Mempengaruhi Penerapan Standar Akuntansi Keuangan Entitas Tanpa Akuntabilitas Publik (SAK ETAP) Pada Usaha Mikro Kecil dan Menengah (UMKM). Jurnal Akuntansi Indonesia, Vol. 5 No. 1, Januari 2016, Hal. 79-98. Fakultas Ekonomi Universitas Muhammadiyah Semarang.

Indriantoro, N. Dan Supomo, B. 2012.ARA Rahmawati, Teti dan Puspasari, Oktaviani Metodologi Peneliitian Bisnis. Edisi Pertama. BPFE anggota IKAPI, Yogyakarta.

Kementrian Koperasi dan Usaha Kecil Menengah Republik Indonesia. 2013. Di unduh dari laman www.depkop.go.id

Jusuf, Al Haryono, 2003. Dasar-dasar Akuntansi Jilid I, Sekolah Tinggi Ilmu Ekonomi YKPN, Yogyakarta. Rita. 2017. Implementasi SAK ETAP dan Kualitas Laporan Keuangan UMKM Terkait Akses Modal Perbankan, Jurnal Kajian Akuntansi, Vol 1, (1), 2017 : 4962. Fakultas Ekonomi, Universitas Kuningan.

Rudiantoro, R., dan S.V. Siregar. 2011. Kualitas Laporan Keuangan UMKM serta Prospek Implementasi SAK ETAP, Simposium Nasional Akuntansi $X V I$. Aceh.

m.liputan6.com/bisnis/read/2930435/bun ga-kur-bakal-turun-jadi-7-persen.

Singarimbun, Masri dan Sofian Effendi. 2005. Metode Penelitian Survey. Jakarta: LP3ES 
Soraya, Elyana Ayu. Mahmud, Amir. 2016. Faktor-Faktor Yang Mempengaruhi Kebutuhan Standar Akuntansi Keuangan Entitas Tanpa Akuntabilitas Publik, Accounting Analysis Journal 5 (1) (2016). ISSN 22526765. Jurusan Akuntansi, Fakultas Ekonomi, Universitas Negeri Semarang.
Sugiyono. (2012). Metode penelitian kombinasi. Bandung : Alfabeta

Undang-Undang Nomor 20 tahun 2008 tentang Usaha Mikro Kecil dan Menengah (UMKM)

Undang-Undang Nomor 28 tahun 2008 tentang Usaha Mikro Kecil dan Menengah (UMKM)

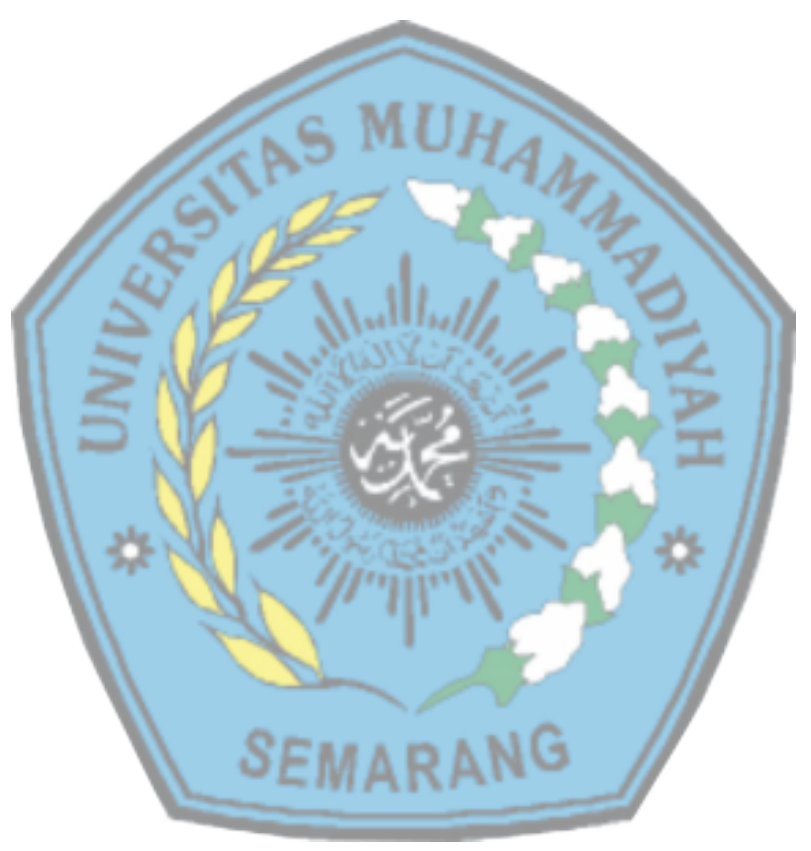

